DOI: $10.14451 / 2.131 .50$

\title{
ПРИРОДООХРАННЫЕ ПРОКУРАТУРЫ В НЕКОТОРЫХ ПОСТСОВЕТСКИХ СТРАНАХ И США
}

\author{
(c) 2019 Куликов Антон Алексеевич \\ студент магистратуры
}

Московский государственный юридический университет им. О.Е. Кутафина «МГЮА», Россия, Москва E-mail: kulikov696@bc.ru

В статье проанализированы особенности природоохранной деятельности прокуратуры в Казахстане, Украине и США.

Ключевые слова: специализированные прокуратуры, природоохранная прокуратура

Во всех странах СНГ существуют специализированные прокуратуры. Они в целом сохраняются, развиваются и функционируют в соответствии с потребностями общества и государства. Это объясняется тем, что такие звенья создавались либо с учетом специфики правовой сферы (природоохранные прокуратуры), либо особенностей объектов надзора (предприятия транспорта, оборонной промышленности, исправительно-трудовые учреждения и т.д.). При этом специализация имеет значение, главным образом, для организации общенадзорной работы.

Согласно законам о прокуратуре государствучастников СНГ военные прокуратуры существуют во всех странах Содружества; транспортные - в Азербайджане, Беларуси, Грузии, Казахстане, Молдове, Таджикистане, Туркменистане и Узбекистане; природоохранные - в России и Казахстане. В Украине, за исключением военной, не регламентированными являются транспортные, природоохранные прокуратуры, а также прокуратуры по надзору за соблюдением законов при исполнении судебных решений по уголовным делам.

Таким образом, в рамках рассматриваемого вопроса представляется целесообразным рассмотреть особенности природоохранной деятельности прокуратуры в Казахстане и Украине.

В Казахстане природоохранная прокуратура зарекомендовала себя в качестве органа, который способен препятствовать нарушению экологического законодательства [1]. Однако, несмотря на это, в деятельности природоохранной прокуратуры имеется ряд недостатков, устранение которых приведет к усилению ее природоохранной деятельности.

Согласно пункту 1 статьи 1 Закона Республи- ки Казахстан «О Прокуратуре» (далее - Закон) Прокуратура Республики Казахстан от имени государства осуществляет высший надзор за точным и единообразным применением законов, указов Президента Республики Казахстан и иных нормативных правовых актов на территории Республики, за законностью досудебного производства, оперативно-розыскной деятельности, административного и исполнительного производства [2].

Природоохранная прокуратура относится к числу специализированной прокуратуры. Известно, что институт специализированной природоохранной прокуратуры зародился недавно. Главным направлением деятельности природоохранной прокуратуры является надзор за применением экологического законодательства Республики Казахстан и природопользованием.

В Республике Казахстан правовой статус и полномочия специализированной природоохранной прокуратуры, помимо Конституции и Закона $\mathrm{PK}$ «О Прокуратуре» отражен в Инструкции по организации прокурорского надзора за применением законов, соблюдением прав и свобод человека и гражданина в социальноэкономической сфере, утвержденной приказом Генерального Прокурора Республики Казахстан от 2 сентября 2014 г. № 85.

Так, в Инструкции предусмотрено, что вопрос применения законодательства об охране окружающей среды и рациональном использовании ее ресурсов относится к приоритету в деятельности природоохранной прокуратуры в сфере надзора за применением законов и соблюдением прав и свобод человека и гражданина [3].

Несмотря на предпринимаемые меры по совершенствованию правового регулирования 
охраны природы, улучшения состояния окружающей среды так и не последовало. В связи с чем именно на специализированную природоохранную прокуратуру возложены задачи адекватного и своевременного реагирования на нарушения природоохранного законодательства и обеспечения реализации права на благоприятную окружающую среду.

С момента создания природоохранная прокуратура зарекомендовала себя в качестве органа, способного отреагировать на экологические правонарушения, воздействовать на уменьшение количества нарушений природоохранного законодательства и содействовать реализации права на благоприятную окружающую среду. В частности, органы природоохранной прокуратуры способствуют реализации права на благоприятную окружающую среду путем проведения прокурорских проверок на предмет соблюдения природоохранного законодательства. Так как согласно пункту 1 статьи 48 Закона РК «О Прокуратуре» в деятельность специализированных природоохранных прокуратур входит проведение проверок на предмет соблюдения требований экологического, водного, санитарно-эпидемиологического законодательства Республики Казахстан [4].

Природоохранная деятельность становится важным направлением деятельности органов прокуратуры. Природоохранная прокуратура обладает обширными полномочиями по надзору в сфере экологии - осуществление взаимодействия с другими государственными органами в сфере экологии, проверка транспортных средств, привлечение к ответственности в сфере экологии, взыскание ущерба, нанесенного окружающей среде. Более того, к деятельности природоохранной прокуратуры также относится надзор за применением антикоррупционного законодательства. Особое внимание заслуживают проводимые природоохранной прокуратурой рейдовые мероприятия с привлечением специалистов уполномоченных государственных органов в целях пресечения и профилактики правонарушений в сфере природных ресурсов.

Органами природоохранной прокуратуры также ведутся профилактические работы по предотвращению фактов незаконного изъятия объектов животного мира (сюда относятся периодические выступления в СМИ), на постоянной основе ведется мониторинг по выявлению самовольного пользования недрами, осуществляется анализ законности принятия местными исполнительными органами нормативно-правовых актов.

Здесь хотелось бы отметить, что в области надзора в сфере экологии важной является деятельность природоохранной прокуратуры по совершенствованию экологического законодательства. Учитывая, что органы природоохранной прокуратуры в большей степени осведомлены о специфике применения природоохранного и экологического законодательства, полагаем, что необходимо способствовать реализации природоохранной прокуратурой функций по совершенствованию экологического законодательства.

Что касается функционирования природоохранных прокуратур в Украине, то, следует отметить, что после внесенных 2 июня 2016 изменений в Конституцию Украины правоохранительные функции прокуратуры в сфере охраны окружающей среды сузились до представительства интересов государства в суде в исключительных случаях и в порядке, которые определены законом. Указанные конституционные изменения имели следствием кардинальное переосмысление роли прокуратуры в природноохранной сфере, что привело к массовой отмене норм отраслевого права и необходимости выработки новых механизмов представительства прокурором интересов государства в сфере защиты окружающей среды [5].

Однако согласно новой редакции Закона было полностью ликвидировано специализированные природоохранные прокуратуры с целью якобы предотвращения дублирования функций прокуратуры с функциями других органов государственной власти в сфере охраны окружающей природной среды.

Исторический опыт свидетельствует, что в нашем государстве уже неоднократно предпринимались попытки ликвидации специализированных прокуратур, но через некоторое время их функционирования возобновляли. Как известно, природоохранные прокуратуры создавались в 1984-1987 годах, в 2012 году их было трансформировано в межрайонные прокуратуры по надзору за соблюдением законов в природоохранной сфере, а в 2014 году - полностью ликвидирован.

Таким образом, согласно новому Закону Украины «О прокуратуре» от 14 октября 2014 ликвидировано широкие полномочия прокуро- 
ров в природоохранной сфере, которая до этого была одним из приоритетных направлений деятельности государства [6]. После вступления в силу этого закона функция прокурорского надзора за соблюдением и применением законов превратилась в функцию представительства прокурором интересов гражданина или государства в суде. Законодательные изменения касаются и ограничение оснований и порядка осуществления прокурором представительства интересов государства в суде, а также возможностей информационного обеспечения представительской деятельности в указанной сфере.

Государственный надзор (контроль) в природоохранной сфере сегодня осуществляют семь органов исполнительной власти: Государственная экологическая инспекция, Государственная служба геологии и недр Украины (Госгеонедра), Государственное агентство лесных ресурсов Украины, Госгеокадастр, Госрыбагентство, Госпродпотребслужба, Государственная служба Украины по безопасности на транспорте. Но на практике нередко все эти органы могут лишь зафиксировать выявленные правонарушения и направить сведения в органы прокуратуры для принятия конкретного решения, предусмотренного Уголовным процессуальным кодексом Украины (УПК Украины).

Общий успех представительства прокурором в суде интересов государства зависит от правильности действий прокурора на каждом этапе его процессуальной деятельности, в частности от правильности определения ответчика, на которого возлагается гражданская (имущественная) ответственность за совершение нарушения природоохранного законодательства. Так, от правового статуса ответчика в спорных правоотношениях зависит отнесение спора к компетенции той или иной формы судопроизводства [7].

Например, в спорах о возмещении вреда, причиненного окружающей природной среде работником (работниками) при исполнении им своих служебных обязанностей, ответчиком будет выступать физическое или юридическое лицо, с которым работник состоит в трудовых отношениях (ст. 1172 ГК Украины). В спорах о возмещении вреда, причиненного окружающей среде источником повышенной опасности, ответчиком будет выступать лицо, которое на соответствующем правовом основании владеет этим источником (ст. 1187 ГК Украины).
Реализуя представительскую функцию интересов государства в сфере охраны окружающей природной среды, прокурор руководствуется нормами природоохранного законодательства об обеспечении экологической безопасности, а по вопросам, не урегулированным этим законодательством, правилами гражданского законодательства.

Согласно ст. 69 Закона Украины «Об охране окружающей природной среды» вред, причиненный в результате нарушения природоохранного законодательства, подлежит компенсации в полном объеме. Вред, причиненный вследствие нарушения этого законодательства, должна возмещаться в размерах, которые определяются на основании утвержденных в установленном порядке тактики и методики расчета размеров ущерба, действующих в момент совершения нарушения.

Осуществляя представительство в суде законных интересов государства, прокуроры нередко ссылаются на ст. 1192 Гражданского кодекса Украины, согласно которой суд, приговаривая возмещения вреда может обязать ответственное за вред лицо возместить его в натуре. Таким образом, восстановление окружающей среды происходит за счет лица, нарушившего природоохранное законодательство об обеспечении экологической безопасности. С этой целью в исковом заявлении прокурора указываются конкретные мероприятия по восстановлению окружающей природной среды, а также сроки их выполнения [8].

С целью представительства законных интересов государства в природоохранной сфере прокурор может не только подавать иск, но и вступать в дело, возбужденное по иску (заявлению, представлению) другого лица, на любом этапе судебного производства. О своем вступлении в дело прокурор письменно уведомляет суд, также обосновывает основания для такого представительства.

Осуществление прокурором эффективного представительства интересов государства в природоохранных отношениях требует широкого круга знаний, высокого уровня осведомленности в этой сфере. С этих позиций автору представляется сомнительным шаг по ликвидации специализированных природоохранных прокуратур и возложение их функций на обычных прокуроров, которые не обладают такими специальными знаниями. Поспешные реформы 
могут привести к ухудшению состояния охраны окружающей природной среды и вследствие этого - к увеличению численности правонарушений в этой сфере.

Таким образом, можно сделать вывод, что политика постсоветских государств в области прокурорского надзора направлена на упразднение специализированных природоохранных прокуратур и сужение их полномочий исключительно к общему надзору.

\section{Особенности деятельности природоох- ранных надзорных органов в США}

Вопрос об особенностях деятельности государственных органов в сфере охраны природы является затруднительным ввиду того, что полномочия прокуратуры США ограничены в рассматриваемой области, а функциями надзора наделены специальные природоохранные органы.

Этот вопрос требует самостоятельного изучения, и он заслуживает более глубокого анализа. Поэтому, представляется целесообразным проанализировать деятельность органов исполнительной власти США на уровне сравнительноправового анализа.

Система органов исполнительной власти США по сравнению с российскими имеет некоторые особенности. Во-первых, форма правления США - президентская республика. Вся исполнительная власть принадлежит президенту. Федеральное правительство и администрация президента - по существу один и тот же орган. Губернаторы и администрация штатов аналогичные структуры правительства, как и на федеральном уровне.

В политической структуре США имеется кабинет, который проводит консультации, выполняет роль совещательного органа помогает принимать важные решения президенту по различным вопросам. Решения могут оформляться правовыми актами президента. Состав кабинета определяется президентом, в него входят руководители ведущих департаментов (министерств): иностранных дел, финансов, обороны, юстиции, внутренних дел. сельского хозяйства, торговли, труда, здравоохранения и социального обеспечения, жилищного и городского строительства. энергетики, транспорта и по делам ветеранов [9].

В систему администрации президента входят исполнительный аппарат, федеральные де- партаменты и агентства.

Исполнительная ветвь власти в США представлена: Советом по качеству окружающей среды, исполнительными департаментами (министерствами), независимыми агентствами и коллегиями. В сфере охраны окружающей среды и природопользования можно отметить: специализированный орган федерального экологического управления - Совет по качеству окружающей среды Исполнительного офиса Президента; Агентство (министерство) по охране окружающей среды, наделенное широкими полномочиями по контролю за выполнение законодательства. Полномочия данных органов являются наиболее близкими к полномочиям природоохранных прокуратур.

В 1970 г. был создан Совет по качеству при президенте. Обязанность Совета - подготовка посланий президента Конгрессу США о состоянии окружающей среды. Совет, являясь рабочим органом президента, участвует не только в определении общенациональной экологической политики, но также его деятельность направлена на реализацию задач, вытекающих из экологического законодательства. Основные функции и полномочия Совета определяются указами президента и Законом 1970 г. «Об улучшении качества окружающей среды». Совет наделен правом законотворческой инициативы в области экологических отношений. Он не наделен административно-властными полномочиями и не дублирует деятельность других органов власти. Совет наделен полномочиями координатора федеральных ведомств по вопросам охраны окружающей среды и издает нормативно-методические документы в этой сфере деятельности.

Создание Совета представляет собой значительное достижение в области осуществления государственного регулирования охраны окружающей среды в США. Его положение на высшем уровне исполнительной власти и задачи отвечают требованиям консолидации и интеграции усилий, обеспечения единого, центрального комплексного подхода к проблеме охраны окружающей среды. Структурная и функциональная независимость Совета от хозяйственных органов способствует преодолению сугубо экономического, ведомственного подхода к использованию природных ресурсов и способствует большей объективности при вынесении решений. 
Специальным органом, уполномоченным решать вопросы охраны окружающей среды, является Агентство по охране окружающей среды (ЕРА). Это самостоятельный федеральный орган исполнительной власти, руководитель которого назначается президентом США и, как правило, утверждается Сенатом. Руководитель ЕРА является членом президентской команды, что говорит о его высоком статусе.

Таким образом, ЕРА осуществляет функции межотраслевого управления. Главными функциями являются: сохранение и улучшение качества трех сфер окружающей среды - водных ресурсов, атмосферного воздуха и земли, а также целостности озонового слоя планеты. К основным видам деятельности ЕРА относятся: нормотворческая, планирование, координация, методическое руководство, обучение и подготовка кадров, научные исследования, техническая помощь, мониторинг, контроль, государственный экологический надзор, финансирование [10].

Специальные функции ЕРА определены законодательными актами. Таким же образом во всех штатах созданы аналогичные ЕРА. На основании действующих в штатах конституций определяются система и структура органов власти и управления, а также их компетенция. Необходимо подчеркнуть, все ЕРА штатов не находятся в административном подчинении федеральному Агентству по охране окружающей среды, а подчиняются только по горизонтали - создававшим их органам власти и управления штатов. Руководители этих органов назначаются губернаторами штатов.

Следует отметить, что департаменты в штатах имеют различные названия, но в целом сущность их деятельности сводится к обеспечению сохранности окружающей среды. К примеру, в штатах Арканзас, Айдахо, Аризона, Вайоминг, Луизиана, Мичиган, Миссисипи, Небраска, Оклахома, Орегон, Юта - они называются департаментами по качеству окружающей среды, а в таких штатах, как Аляска и Нью-Йорк - департаменты по обеспечению сохранности окружающей среды. В других штатах: Коннектикут, Массачусетс, Мэн, Нью-Джерси, Флорида - департаменты по охране окружающей среды. В штате Иллинойс имеется Комитет по контролю за загрязнением окружающей среды, кроме существующего департамента, а в штате Кентукки создан Департамент по обеспечению сохранности природных ресурсов и наряду с этим орга- ном существует Комиссия по качеству окружающей среды. В некоторых штатах на эти органы, помимо выполняемых функций по охране окружающей среды, возлагаются и другие функции, не связанные с охраной природы. Так в штатах Канзас и Колорадо на департамент, выполняющий функции охраны природных ресурсов, возложены и такие функции, как охрана здоровья граждан.

Следует отметить, что структура органов специальной компетенции в США по организации их природоохранной деятельности и природопользованию определяется особенностями самих штатов, включая климатические, географические, экономические, социальные условия, а также перспективы развития этого штата. Более подробно деятельность департаментов штатов в области охраны окружающей среды можно рассмотреть на примере южного штата Калифорния, где численность населения составляет 37.3 млн. человек, что гораздо выше плотности населения в других штатах. Агентство по охране окружающей среды штата (Ca1/EPA) является самостоятельным ведомством в правительстве штата.

Структура (Ca1/EPA) состоит из пяти подразделений: департаменты по вопросам атмосферного воздуха, контроля водных ресурсов, по вопросам использования пестицидов, по контролю за токсичными веществами и Отдел по вопросам улучшения качества окружающей среды и охраны здоровья людей. Все департаменты наделены определенными функциями, начиная от научных исследований до обеспечения соблюдения и исполнения природоохранных законодательных норм. Осуществляют мониторинг качества окружающей среды, оказывают помощь бизнесу в деле соблюдения норм и правил охраны окружающей среды, организуют и проводят мероприятия по повышению экологического воспитания граждан. Все отделения осуществляют свою деятельность совместно с другими службами, а особенно межведомственным Национальным комитетом по борьбе с загрязнением окружающей среды в результате разлива нефти и выброса в окружающую среду вредных загрязняющих веществ.

Также как и ЕРА департаменты штатов в области охраны окружающей среды осуществляют свою деятельность в двух направлениях: во-первых, взаимодействуют со всеми федеральными ведомствами, которые управляют охраной окру- 
жающей среды, и во-вторых, взаимодействуют с соответствующими структурными подразделениями штатов. В связи с этим важную роль играет EPA поскольку она выполняет функции координатора всех департаментов штатов. Помимо нормотворческой деятельности, ЕРА разрабатывает программы в области охраны окружающей среды, которые утверждаются на всех уровнях государственного управления: федеральном, штатов, местном (региональном), локальном [11].

В свою очередь, штаты представляют свои отчеты по проделанной работе в соответствии с программой и законодательными нормами (стандарты штатов, правил, регламентов). Определенные функции по охране окружающей среды выполняют Департаменты (министерства): внутренних дел, обороны, сельского хозяйства, энергетики, торговли, здравоохранения и социального обеспечения, жилищного строительства и развития городских инфраструктур, продовольствия и лекарств, безопасности и охраны здоровья работников.

В ведении Департамента внутренних дел находятся парки и федеральные земли. Департамента сельского хозяйства - пестициды. Департамента энергетики - энергоресурсы. Департамента здравоохранения и социального обеспечения - пищевые продукты и лекарства. Комиссии по использованию ядерной энергии вопросы безопасности ядерных электростанций. Департамента торговли - морские и прибрежные ресурсы.

Главная задача правоохранительных ведомств США - управление землями, а не функции охраны общественного порядка и обеспечение безопасности граждан, как это осуществляется в России органами внутренних дел. В США, кроме названных органов исполнительной власти, в качестве самостоятельных ведомств выступают федеральные агентства по управлению лесами в составе Министерства сельского хозяйства. Служба береговой охраны США в составе Департамента (министерства) национальной безопасности, которая выполняет военные и гражданские функции. Кроме того, существует Национальная администрация по вопросам океана и атмосферы, являющаяся федеральным ведомством в составе Министерства торговли и выполняющая природоохранные функции. Кроме того, в составе Министерства юстиции имеется департамент, занимающийся вопросами окружающей среды и природных ресурсов. В частности, департамент занимается ведением гражданских и уголовных дел об экологических правонарушениях [12].

Таким образом, мы видим, что в США исполнительные органы осуществляют свои действия, не дублируя друг друга, а взаимодействуют со всеми другими службами, ведомствами выполняющими функции природоохранного законодательства. Важно отметить, что штатам предоставляется самостоятельность в решении экологических вопросов, вытекающих из законов как на федеральном уровне, так и на у ровне штатов. Поэтому, представляется актуальным создание специальных судов либо отделов по производству рассмотрения экологических дел в Российской Федерации.

\section{Библиографический список}

1. Султанбекова Г.Б. Некоторые вопросы деятельности прокуратуры в сфере экологической безопасности / Г.Б. Султанбекова // Вестник Карагандинского государственного университета.- 2014. - С. 3-6.

2. Закон Республики Казахстан от 21 декабря 1995 г. «О Прокуратуре».- URL: Справочная правовая система «Параграф»

3. Приказ Генерального прокурора Республики Казахстан от 2 сентября 2014 г. № 85 «Об утверждении Инструкции по организации прокурорского надзора за применением законов, соблюдением прав и свобод человека и гражданина в социально-экономической сфере».-URL: http://adilet.zan.kz/rus/docs/V14W0009773

4. Природоохранная прокуратура ЮКО взыскала в бюджет более 90 млн. тенге._ URL: http://www.newsfactory. kz/2016/01/02/prirodoohrannaya-prokuratura-yuko-vzyskala-v-yudzhet- bolee-90-mln-tenge.html

5. Рибалка Н. О. Особливо стіви значення системи та структур и органів прокуратури України / Н. О. Рибалка // Часопис Київського університету права. - 2013. - № 1.- С. 284-287

6. Про прокуратуру: Закон Українивід 14 жовтня 2014 року № 1697-VII // Відомості Верховної Ради України.2015. - №№ 2-3. - Ст. 12.

7. Сухонос В.В. Прокуратура в механізмі української держави: проблеми теорії та практики [Текст]: автореф. дис... д-ра юрид. наук: 12.00.10 / Сухонос Віктор Володимирович; Одеська національна юридична академія.- О., 2009. С. 48 
8. Олійник Р. В. Система та структура прокуратури України / Р.В. Олійник // Європейські перспективи. - 2014. № $1 .-$ С. 33-39.

9. Браславский Л.И. Экология и охрана окружающей среды: законы и реалии США и России: моногр.- М.: Инфра-М. 2013.- С. 67-68.

10. Пронкин С.В., Петрунина О.Е. Государственное управление зарубежных стран: Учеб.пособие.- 3-е изд., доп. и перераб.-М.: КДУ, 2007. С. 54

11. Конституции зарубежных государств: Великобритания, Франция, Германия, Италия, Соединенные Штаты Америки, Япония, Бразилия: Учеб. пособие / Сост. сб., пер., авт. введ. и вступ. ст. В.В. Маклаков.-6-е изд., перераб. и доп.-М.: ВолтерсКлувер, 2009. С. 38

12. Реймерс Н.Ф. Охрана природы и окружающей человека среды: опыт США.- М., 2006. С. 47

13. Бернам У. Правовая система США. 3-й выпуск / Уильям Бернам. - [пер. с англ.: Александров А.В., Власихин В.А., Коновалов А.Л. и др.]; научн. ред. Власихин В.А.- М.: Новая юстиция, 2006. С. 339

14. Кит Р. Криддл Правовые основы управления рыбными ресурсами в США и эволюция основанного на правах управления рыбными ресурсами на Аляске / Internationalfisherycongress: [Электронный ресурс].- Режим доступа: http://fish-forum. ru/files/98.doc.

15. United States Environmental Protection Agency. - [Электронныйресурс]. - Режимдоступу: http://www.epa.gov.

16. Волков А.М. Органы управления природопользованием и охраной окружающей среды в США [А.М. Волков, Е.А. Лютягина, А.С. Линьков].- Вестник Российского университета дружбы народов, 2010.- № 3. - С. 7685 . 